\title{
Evidence of Opportunity and Necessity Driven Entrepreneurship in Nigeria
}

\author{
Abubakar S. Garba*,Fariastuti Djafar**, \\ Shazali Abu Mansor***
}

\begin{abstract}
The objective of this paper is to examine the influence of poverty, unemployment and GDP on entrepreneurship. Time series data for 31 years was collected from various official sources for the analysis. Vector autoregressive (VAR) framework was adopted to systematically capture the rich dynamic of multiple time series. Other tests conducted were unit root test, Johansen and Juselius (1990) co-integration test, Granger causality and dynamic model analysis beyond the sample. It was found that poverty and GDP influence entrepreneurship negatively, while unemployment influences entrepreneurship positively. The paper reveals the presence of both opportunity and necessity driven entrepreneurs in the country. There is a need for the government to revisit the existing policy on micro, small and medium enterprises (MSMEs) to adequately address the problem of the poor and unemployed by availing them with the opportunity to engage in entrepreneurship. Future study should consider mitigating the effect of frequent entry and exit from entrepreneurship in their data to correctly predict the effect of entrepreneurship on the economy.
\end{abstract}

Keywords: entrepreneurship development, poverty, unemployment, GDP.

\section{Introduction}

The potential of entrepreneurs to harness the necessary resources and create vibrant economy is increasingly being recognized in developing countries. The significance of micro, small and medium enterprises (MSMEs) has been recognized globally in terms of productivity and competitiveness of the economies. MSMEs are the primary source of job creation, nurturing ground for entrepreneurial capabilities, innovativeness as well as providing managerial competency for private sector development. MSMEs play a key role in developing countries that are characterized with high level of unemployment and poverty.

\footnotetext{
* Ph.D., Department of Business Admin \& Management, School of Management Studies, Kano State Polytechnic, Nigeria, abubakarsg@yahoo.com

** Ph.D., Department of Economics, Faculty of Economics and Business, Universiti Malaysia Sarawak, Malaysia, dfariastuti@feb.unimas.my

*** Prof., Department of Economics, Faculty of Economics and Business, Universiti Malaysia Sarawak, Malaysia.
} 
Looking at the present realities and challenges facing Nigeria, the need to develop entrepreneurship became apparent. Developing strong, vibrant and viable MSMEs is necessary in order to solve its numerous socioeconomic problems. In 2010 the estimated population of Nigeria was about 163 million people out of whom about $70 \%$ are classified as poor based on the international poverty threshold of less than 1.25 dollars per day. In 1980 the poverty incidence and estimated poor population was just $27.2 \%$ and 17.7 million, but it escalated to $69 \%$ and 112.5 million respectively in 2010 . Similarly, unemployment rate was $13.1 \%$ in 2000 , but rose to $21.4 \%$ in 2010 . In spite of the increase in both poverty and unemployment, the Nigerian economy has achieved continuous improvement from 2005 to 2010 with the exception of 2008 where GDP growth rate slightly decreased to $5.98 \%$ and grew immediately by $6.95 \%$ in the subsequent year (NBS, 2010).

There is a great opportunity for entrepreneurship in the country and entrepreneurial activity has the potentials of addressing the incessant problem of poverty and unemployment. Entrepreneurship development requires more than a policy pronouncement, but action must be taken to provide a conducive business environment particularly for the micro and small business to emerge and prosper. It is noted that there is no previous study that examines the influence of GDP, unemployment and poverty on entrepreneurship at the same time. Generally, there is paucity of studies that examine the influence of GDP and poverty on entrepreneurship. Therefore, this paper attempts to fill this research gap by examining the influence of poverty, unemployment and GDP simultaneously on entrepreneurship in which no previous study does so in Nigeria context. The objective of this paper is to examine the influence of poverty, unemployment and GDP on entrepreneurship.

\section{Literature review}

Entrepreneurship plays an important role in boosting productivity, increasing competition and innovation, creating employment and economic prosperity (Ritche and Lam, 2006). Entrepreneurship is synonymous with business start up or creation of new organization (Keister, 2005). There are several factors influencing entrepreneurship in both developed and developing countries. The nature and dynamics of entrepreneurship is dependent on the country's level of economic development. The pattern and type of entrepreneurs are based on how socio-economic variables affect entrepreneurship in the country. The refugee/push and Schumpeterian/pull effect hypotheses provide the basic understanding of the relationship between entrepreneurship, poverty, unemployment and GDP (Audretsch et al., 2001). The relationship 
between entrepreneurship and the macroeconomics variables are discussed as follows:

Entrepreneurship and Poverty: The long term analysis of economic and social development, particularly on poverty reduction, is very important in discussing any developmental issues (Szirmai, 2005). Poverty reduction should also be the ultimate goal of all development endeavors (Akoum, 2008). Poor people are motivated to engage in micro and small scale business to sustain their lives and possibly get out of poverty. They can make a difference by turning themselves into entrepreneurs to productively and economically contribute to the society. Poor economic conditions lead to higher entrepreneurial activities in many developing countries than in the developed countries. However, the frequent and high entry and exit is noted among people who have started business out of necessity.

Rosa, Kodithuwakkub and Balunya (2006) in Uganda and Sri Lanka found that poverty significantly influences entrepreneurial activity. Mulira, Namatovu and Dawa (2011) in Uganda reveal negative and significant relationship between poverty and entrepreneurship. Block and Sandner (2009) and Wanger (2005) in Germany and Verheul, Thurik, Hessel and Zwan (2010) in 27 European countries and the US discovered that there were more opportunity than necessity entrepreneurs in these countries.

Entrepreneurship becomes inevitably the last option particularly for the poor in an economy where employment opportunities are not readily available. The poor can be creative and exert high impact through radical innovations. The idea of creative destruction is built on dynamic, deliberate entrepreneurial effort to change market structures and make use of profit opportunities that exists. It is interesting to find whether high rate of entrepreneurial activity due to necessity could be translated into economic growth or not. This may depend on the situation and level of economic development of a particular country in which the entrepreneurs exist. Both opportunity and necessity entrepreneurs can be found in both developed and developing countries.

Entrepreneurship and Unemployment: There are an increasing number of studies on the relationship between unemployment and entrepreneurship. Most of the previous studies used cross sectional or longitudinal data at micro level and time series data at macro level (Meager, 1992). The entry into entrepreneurship by unemployed people has attracted the attention of many researchers and policy makers. The propensity to start a business because of unemployment is very important to public policy (Audretsch and Jin, 1994). That is why many governments in both developed and developing countries are encouraging and supporting unemployed people to start up business. Evan and Leighton (1990) in the US studied small businesses started and operated 
by both unemployed and employed workers. It was discovered that entry into entrepreneurship was higher for the unemployed than for the employed people. The relationship between entrepreneurship and unemployment is not clear but empirical studies revealed two ways of relationships. One strand of the studies confirmed that unemployment stimulates entrepreneurial activity which is referred to as refugee effect, while the other body of the literature confirms that high entrepreneurial activity influences reduction of unemployment which is known as Schumpeterian effect.

Unemployment is positively related to new firm start ups in 23 OECD countries (Audretsch et al., 2001). Other studies found positive influence of unemployment on entrepreneurship (Reynolds, Storey and Westhead, 1994; Evans and Leighton, 1989 and Highfield and Smiley, 1987). While Garofi (1994) in UK, Audretsch and Fritsch (1994) in Germany indicate that unemployment is negatively related to new firm start up. Audretsch and Thurik, (2000) believe that new business could possibly generate employment thereby cutting down the rate of unemployment. Hamilton (1989) and Faria, Cuestas and Mourelle (2010) suggest that the relationship between entrepreneurship and unemployment can be bidirectional and non linear. Carree (2002) in the US found that there is no significant relationship between the variables.

In another dimension, entrepreneurial activity reduces unemployment and could have positive effect on economic performance in different ways. Stel et al. (2007) and Audretsch et al. (2001) attempted to reconcile this ambiguous relationship using data from 23 OECD countries between 1974 and 1998. Phehn-Dujowich (2012) in the US discovered that the unemployment has Granger causal effect on entrepreneurship. Storey (1991) provided an explanation which looks like a consensus on the relationship between unemployment and entrepreneurship.

Entrepreneurship and GDP: The link between entrepreneurship and GDP can be traced to Schumpeter's work which highlights the role of entrepreneurs in creating disequilibrium through the process of creative destruction (new combination). Schumpeterian entrepreneurs are productive, innovative and opportunity seekers (Sexton and Kasarda, 1992). In a period of high economic growth there will be proliferation of opportunity entrepreneurs, who make high impact and promote economic development (Mojica-Howell, Whittaker, Gebremedhin and Schaeffer, 2012 and Jones-Evans, Brooksbank and Aaron, 2006). High level of GDP may lead to increasing economic prosperity which in turn affects consumption and investment (Hartog, Parker, Stel and Thurik, 2010). The increase in consumer demand and services due to economic prosperity will create opportunities for entrepreneurs (Audretsch and Keithbach, 2004). On the other side, low GDP creates necessity entrepreneurs who start up business because of poor economic condition characterized 
by limited options for wage employment due to low demand for goods and services. This situation reflects the 'push / recession hypotheses'.

Some previous studies attempted to investigate two directional relationships between GDP and entrepreneurship (Thurik, Carree, Stel and Audretsch, 2008 and Mojica-Howell et al., 2012). Other studies try to examine the influence of economic growth on entrepreneurship (Storey, 2003). Entrepreneurship is likely to be endogenous where high level of GDP has a strong incentive for opportunity based business start up. It was found in the US by Phehn- Dujowich (2012) that economic growth causes entrepreneurship (Granger causality). Hartog et al. (2010) found evidence of long run equilibrium relation between entrepreneurship (business ownership) and economic growth measured by per capita income.

The relationship between necessity entrepreneurship and GDP is likely to be negative for developing countries and positive for developed nations. Koster and Rai (2008) discovered that in India the increase in GDP does not go with the decreasing rate of entrepreneurial activity as expected in the Global Entrepreneurship Monitor (GEM) model. Their result shows a weak positive relationship between economic growth and entrepreneurship in least developed regions. Stel, Carree and Thurik (2004) in GEM countries found that there is a significant linear effect between total entrepreneurial activities (TEA) and GDP growth. They also discovered a significant nonlinear effect which shows a negative effect in relatively poor countries and positive effect in relatively rich countries. Salgado-Banda (2005) in 22 OECD countries found both positive and negative relationship using two different measures of entrepreneurship. GEM research work represents one most important analysis and source of data for global entrepreneurial activity and particularly provides a link between entrepreneurship and economic growth (UNCTAD, 2004). GEM believed that the traditional view on GDP and economic competitiveness neglected the role of entrepreneurship (new and small business) in the economy.

The developing countries are assumed to have a high number of necessity entrepreneurship because of the unbearable condition and the need to survive (Koster and Rai, 2008). Opportunity entrepreneurship tends to pick up as the economy improves when people consider it safe to abandon self employment for wage employment. The prevalence of opportunity and necessity can be depicted in a $U$ shaped curve which is termed as $U$ shaped curve hypothesis (Bosma et al., 2008; Koster \& Rai, 2008; Wennerkers et al., 2005). In the early stage of development there will be a higher rate of business creation, but as the country's GDP per capita increases there will be a decrease in the rate of business creation. ON the other hand, in the later 
stage the relationship tends to be positive, which means increase in GDP per capita causes increase in the rate of new business creation.

\section{Data and method}

This section deals with the methodology. It explains the model specification, defining and measuring variables and method of data analysis as follows; Econometrics model specification:

$$
\text { LENT }_{t}=\beta_{o}+\beta_{1} \text { LPOV }_{t}+\beta_{2} \text { LUEM }_{t}+\beta_{3} \text { LGDP }_{t}+\mu_{t}
$$

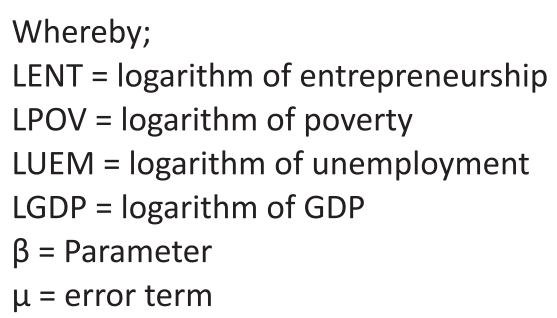

\section{Defining and measuring variables}

Entrepreneurship:Newbusinesscreation is used as a proxy forentrepreneurship as adopted by the previous studies (Wang, 2006; Sternberg and Wennekers, 2005; and Lafuente and Driga, 2007). It is defined as the number of micro and small business created annually in the country. The data was collected from Corporate Affairs Commission (CAC), Nigeria.

Poverty: The National Bureau of Statistics adopted World Bank international poverty threshold of $\$ 1.25$ per day for Sub-Saharan Africa for measuring poverty in absolute term. Therefore any person with income below this official threshold is considered to be poor. In this case the number of poor people was used as a measure of poverty. The limitation of this measure is that in Nigeria consumer survey on poverty is not conducted on a yearly basis. Data for other years was obtained based on annual poverty projection. The data was obtained from National Bureau of Statistics for 31 years.

Unemployment: Unemployment is defined as a situation where someone of working age would like to be in full time employment, but is unable to get a job. In this paper the number of registered unemployment was used. The data for the registered unemployed was obtained from Federal Ministry of Labour and Productivity, Nigeria. The limitation of this data is that many unemployed people may not be included in the study because they did not register as unemployed in the Ministry.

Gross domestic product: It is basically the amount of goods and services produced in a country over a specific period of time. In this paper absolute 
value of real GDP was used as a measure for the period between 1980 and 2010. The data for real GDP was collected from Central Bank of Nigeria (CBN).

\section{Data analysis}

Vector autoregressive (VAR) framework is used to provide a systematic way of capturing rich dynamic in multiple time series. It is useful in data description, forecasting, structural inference and policy analysis (Stock and Watson, 2001; and Gujarati and Porter, 2009). The tests conducted were unit root (augmented Dickey-Fuller and Phillips-Perron), Johansen and Juselius (1990) co-integration, error correction model (ECM) and Granger causality, variance decompositions and impulse response function. The Vector error correction model (VECM) is represented by the following equations in which each variable become endogenous;

$$
\begin{aligned}
& \mathrm{ENT}_{\mathrm{t}}=\alpha_{0}+\delta_{0} \mathrm{ENT}_{\mathrm{t}-1}+\delta_{1} \mathrm{GDP}_{\mathrm{t}-1}+\delta_{2} \mathrm{POV}_{\mathrm{t}-1}+\delta_{3} \mathrm{UEM}_{\mathrm{t}-1}+\lambda_{0} \mathrm{ECT}_{\mathrm{t}-1}+\mathrm{e}_{\mathrm{t}} \\
& \mathrm{GDP}_{\mathrm{t}}=\alpha_{0}+\delta_{0} \mathrm{GDP}_{\mathrm{t}-1}+\delta_{1} \mathrm{ENT}_{\mathrm{t}-1}+\delta_{2} \mathrm{POV}_{\mathrm{t}-1}+\delta_{3} \mathrm{UEM}_{\mathrm{t}-1}+\lambda_{0} \mathrm{ECT}_{\mathrm{t}-1}+\mathrm{e}_{\mathrm{t}} \\
& \mathrm{POV}_{\mathrm{t}}=\alpha_{0}+\delta_{0} \mathrm{POV}_{\mathrm{t}-1}+\delta_{1} \mathrm{ENT}_{\mathrm{t}-1}+\delta_{2} \mathrm{GDP}_{\mathrm{t}-1}+\delta_{3} \mathrm{UEM}_{\mathrm{t}-1}+\lambda_{0} \mathrm{ECT}_{\mathrm{t}-1}+\mathrm{e}_{\mathrm{t}} \\
& \mathrm{UEM}_{\mathrm{t}}=\alpha_{0}+\delta_{0} \mathrm{UEM}_{\mathrm{t}-1}+\delta_{1} \mathrm{ENT}_{\mathrm{t}-1}+\delta_{2} \mathrm{GDP}_{\mathrm{t}-1}+\delta_{3} \mathrm{POV}_{\mathrm{t}-1}+\lambda_{0} \mathrm{ECT}_{\mathrm{t}-1}+\mathrm{e}_{\mathrm{t}}
\end{aligned}
$$

Where ECT is the error correction term measuring the speed of adjustment to the long run equilibrium, and $\alpha, \delta, \lambda$ are estimated parameters

\section{Results and discussion}

\section{Unit root test results}

In Table 1 and 2 the results of Augmented Dickey fuller (ADF) and Phillips Perron (PP) unit root tests are shown respectively. The results indicate that the null hypotheses of presence of a unit root or non-stationarity in both methods cannot be rejected at level form, but it can be rejected after first differencing at $1 \%$ level of significance. 
Table1. Unit root test - Augmented Dickey-Fuller (ADF)

\begin{tabular}{lcccc}
\hline Variable & \multicolumn{2}{c}{ Level } & \multicolumn{2}{c}{ First Difference } \\
\hline & Intercept & $\begin{array}{c}\text { Intercept with } \\
\text { trend }\end{array}$ & Intercept & $\begin{array}{c}\text { Intercept with } \\
\text { trend }\end{array}$ \\
LENT & $-2.1361(0)$ & $-2.9055(0)$ & $-5.5600(0)^{* * *}$ & $-5.4656(0)^{* * *}$ \\
LPOV & $-1.2808(1)$ & $-2.2534(1)$ & $-5.7494(0)^{* * *}$ & $-5.7140(0)^{* * *}$ \\
LUEM & $-0.3635(0)$ & $-2.6438(0)$ & $-5.7646(0)^{* * *}$ & $-5.6316(0)^{* * *}$ \\
LEG & $1.1616(0)$ & $-1.3405(1)$ & $-8.5310(0)^{* * *}$ & $-8.5952(0)^{* * *}$ \\
\hline
\end{tabular}

Note:*** denote statistical significance at $1 \%$ level. The critical value of ADF can be found in Mackinnon (1996). The optimum lag length in the test was selected automatically based on Schwarz Information criterion. Lag selection figures are shown in ( ). In ADF, null hypothesis indicating presence of unit root was examined against alternative for stationarity. LENT is a natural log of ENT, LPOV is a natural log of POV, LUEM is a natural log of UEM, LGDP is a natural log of GDP.

Table 2. Unit root test - Phillips-Perron (PP)

\begin{tabular}{lcccc}
\hline Variable & \multicolumn{2}{c}{ Level } & \multicolumn{2}{c}{ First Difference } \\
\hline & Intercept & $\begin{array}{c}\text { Intercept with } \\
\text { trend }\end{array}$ & Intercept & $\begin{array}{c}\text { Intercept with } \\
\text { trend }\end{array}$ \\
LENT & $-1.8383(5)$ & $-2.8715(3)$ & $-7.8855(16)^{* * *}$ & $-9.3802(18)^{* * *}$ \\
LPOV & $-1.4925(2)$ & $-2.5001(2)$ & $-5.7400(2)^{* * *}$ & $-5.7095(1)^{* * *}$ \\
LUEM & $-0.2637(6)$ & $-2.6758(1)$ & $-5.9593(7)^{* * *}$ & $-5.7995(7)^{* * *}$ \\
LEG & $0.8177(2)$ & $-2.6758(3)$ & $-8.3547(1)^{* * *}$ & $-8.3250(2)^{* * *}$ \\
\hline
\end{tabular}

Note:*** denote statistical significance $1 \%$ level. The critical value of PP can be found in Mackinnon (1996). The optimum lag length in the test was selected automatically based on Newey-West estimator using lag selected by Bartlett kernel information criterion. Lag selection figures are shown in ( ). In PP null hypothesis indicating presence of unit root was examined against alternative for stationarity. LENT is a natural log of ENT,LPOV is a natural log of POV, LUEM is a natural log of UEM, LGDP is a natural log of GDP.

The results from the two testing procedures clearly show that the variables are I(1) integrated order of 1 . It is stated that most of the macroeconomic variables are I(1) process (Gujarati and Porter, 2009; Bahmani-Osokoee,1995). Based on these results and having the same order of integration, it is found suitable to proceed to co-integration test to examine the long run relationship among variables.

\section{Co-integration and hypothesis testing results}

The result of Johansen cointegration test is presented in the Table 4 and the selection of lag length performed using Schwarz information criterion (SIC) can be seen in Table 3. 
Table 3. Lag selection based on multivariate SIC

\begin{tabular}{cc}
\hline Lag & SIC \\
\hline 0 & 3.290467 \\
1 & $-2.627118^{*}$ \\
2 & -1.652972 \\
\hline
\end{tabular}

Note: SC refers to Schwarz Information Criterion. Asterisk * denotes the optimum lag selected for VAR estimation in Eviews

From Table 4 panel a the co-integration result reveals that the null hypotheses that states no co-integrating vector $(r=0)$ is rejected in both max eigen value and trace tests, therefore alternative hypothesis is accepted indicating 1 co-integrating vector. This means that the variables in the system share a common trend and move toward one direction in the long run. The result in Table 4 panel B shows normalized co-integrating vector. The coefficients indicate the long run elasticity of the variables. It can be seen that poverty (LPOV) has negative effect on entrepreneurship (LENT). This means that keeping other variables constant, any increase in poverty will decrease the rate entrepreneurship by $.13 \%$ points.

Table 4. Co-integration and hypothesis testing result

\begin{tabular}{lccccc}
\hline Ho & HA & $\begin{array}{c}\text { Max eigen } \\
\text { value }\end{array}$ & $\mathbf{9 5 \% ~ C V}$ & Trace & 95\% CV \\
\hline \multicolumn{7}{r}{ Panel A: Johansen multivariate test } \\
$r=0$ & $r=1$ & $28.9815^{* *}$ & 27.5843 & $48.9196^{* *}$ & 47.8561 \\
$r \leq 1$ & $r=2$ & 15.0945 & 21.1316 & 19.9381 & 29.7970 \\
$r \leq 2$ & $r=3$ & 4.7803 & 14.2646 & 4.8435 & 15.4947 \\
$r \leq 3$ & $r=4$ & 0.0631 & 3.8414 & 0.0631 & 3.8414 \\
$\begin{array}{l}\text { Panel B: Normalizing the co-integrating vector } \\
\text { Variables }\end{array}$ & LENT & LPOV & LUEM & LGDP \\
& -1.000 & 0.1346 & 0.9603 & -0.2093 \\
\hline
\end{tabular}

Notes: $r$ indicates number of co-integrating relationships. Asterisks $(* *)$ indicate $5 \%$ level of significance.

The negative effect of poverty on entrepreneurship supports the findings of Rosa, et al. (2006) in Uganda and Sri Lanka, Mulira et al. (2011) in Uganda, Block and Sandner (2009) and Wagner (2005) in Germany and Verheul et al. (2010) in 27 European countries and the US. This result reveals the existence of opportunity entrepreneurship as poverty cannot stimulate most of the poor to engage in entrepreneurial activities. The finding also reflects pull/prosperity effect which points that people decide to enter into entrepreneurship because of the existing opportunity rather than poverty. 
Since about $70 \%$ of Nigerian population are poor, they probably lack resources to enable them to meet their basic needs and engage in entrepreneurial activity. Various government regimes in the past have attempted to promote entrepreneurship in order to address the problem of poverty through enactment policies and programs such as National Poverty Eradication Program (NAPEP), Poverty Alleviation Program (PAP), Family Economic Advancement Program (FEAP) and Family Support Program (FSP). The negative relationship between entrepreneurship and poverty is a clear indication that these policies and programs did not make significant impact on entrepreneurship to reduce poverty. Moreover, one of the important means through which the millennium development goal of halving poverty can be attained is to empower the poor people to massively engage in entrepreneurship, otherwise the MGDs target for 2015 will remain elusive.

It also appears that unemployment (LUEM) influences entrepreneurship positively. The result shows that any increase in unemployment will increase the rate of entrepreneurship by $.96 \%$ points holding other variables constant (see table 4). This indicates that as unemployment is increasing, the rate of entrepreneurship is also increasing. This result corroborates the findings of Yamawaki (1990) in Japan, Audretsch et al. (2001) in 23 OECD countries, Highfield and Smiley (1987) and Evan and Leighton (1989) in US, Ritsila and Tervo (2002) in Finland, and Reynolds et al. (1994) in France, Germany, Ireland, Italy, Sweden, UK and US. The result also indicates that people in the country become entrepreneurs because of threat of unemployment. This reflects the existence of refugee effect/push hypothesis in which unemployed persons are motivated to start up their own business because there is no prospect of getting paid jobs due to macroeconomic instability or depressed market condition (Storey, 1991).

The rate of unemployment is high (23.9\% in 2011) in Nigeria, therefore the unemployed can have only two options either to start up their business or keep searching for employment opportunities elsewhere. However, the decision in this regard is dependent on the relative payoff in the environment. People in the country can exercise their latent potentials to form new business as the unemployment rate is increasing (Hamilton, 1989). The dimension of entry into entrepreneurship varies between unemployed and employed people. Evan and Leighton (1990) in the US found that entry into entrepreneurship is high among unemployed than those who are already employed. Although unemployed are motivated to start business because of lack of paid job, they have different mission on how they want to promote their business. The rate of business start up by the unemployed could be accelerated based on the conditions and other environmental factors in the country. The extent to 
which unemployment influences the rate of entrepreneurship is very crucial in the realm of public policy (Audretsch and Jin, 1994).

The government of Nigeria also came up with various policies and programs to support unemployed persons to become entrepreneurs. These include the formation of National Directorate for Employment (NDE) in 1986 which is saddled with the responsibility of training and supporting the unemployed to become self reliant by starting their own business. The recent introduction of entrepreneurship courses in all tertiary institutions across the country which is aimed at providing necessary training and business skills to the students is another complementary effort to address the problem of youth unemployment. This is particularly designed to relieve the graduates from the problem of unavailable vacancies in the labor market.

The result further reveals that GDP (LGDP) affects entrepreneurship negatively. It indicates that any increase in economic growth will reduce entrepreneurship entry by about $.21 \%$ points. This result reflects the left hand side of $U$ curve shaped hypothesis for developing countries and is supported by the findings of Carree, Stel,Thurik and Wennekers (2002), Stel et al. (2004), Wennekers et al. (2005) Naude, et al. (2012) and Acs (2007) in GEM countries and Koster and Rai (2008) in India. From the previous studies the relationship between entrepreneurship and GDP is more likely to be positive for developed countries and negative for developing countries (Acs, 2007 and Acs, Desai and Hessels, 2008).

In developing countries at the initial stage where people face poor economic conditions such as low income and high unemployment they may not have other option than to engage in entrepreneurial activity as a means of survival. There will be a proliferation of many necessity entrepreneurs at this stage, but with the improvement of country's economic conditions these necessity entrepreneurs will decline their interest in entrepreneurial activity leaving only opportunity entrepreneurs. This negative relationship is an indication that as country's GDP is increasing the rate of necessity entrepreneurship is decreasing. The reason is that the necessity entrepreneurs may not have necessary interest and enthusiasm to cope with the intense competition generated in the market and harsh business environment in Nigeria. They would find that it is easier to look for paid employment rather than continuing with their business or starting a new one again.

\section{Short run Granger causality and VECM results}

Sequel to the detection of co-integration relation, the proper VAR framework that studies the dynamic relationship between variables must include error correction term (ECT). Thus, VECM provides a way to examine both short run 
and long run causal relationship among variables in the model. The result of Granger causality among the variables is presented in the Table 5.

Table 5. VECM and short run Granger causality result

\begin{tabular}{lcccccc}
\hline $\begin{array}{l}\text { Dependent } \\
\text { Variables }\end{array}$ & \multicolumn{3}{c}{ XLENT } & $\Delta$-Statistics & \multicolumn{2}{c}{ ECT } \\
\hline$\Delta$ LENT & - & $4.9881(0.026)^{* *}$ & $2.0555(0.152)$ & $1.6682(0.197)$ & -0.1467 & -1.5652 \\
$\Delta$ LPOV & $0.0809(0.776)$ & - & $6.1019(0.014)^{* *}$ & $11.768(0.001)^{* * *}$ & $-0.1836^{* * *}$ & -5.2393 \\
$\Delta$ LUEM & $0.3588(0.549)$ & $2.0593(0.151)$ & - & $0.3350(0.563)$ & -0.1082 & -0.7852 \\
$\Delta$ LGDP & $0.0203(0.887)$ & $0.9732(0.324)$ & $1.4282(0.232)$ & - & $-0.0388^{* *}$ & -2.4226 \\
\hline
\end{tabular}

Note: The VAR was based on 1 year lag structure and a constant. ***, **, * indicates statistical significance at $1 \%, 5 \%, 10 \%$ level respectively. Figures in parenthesis ( ) are $p$-value.

The result shows that LPOV and LGDP equation have ECT that is statistically significant which indicates that these variables are responsible for the short run adjustment to bring back the system to long run equilibrium. Without any innovation due to LPOV in the short run, the speed of adjustment will be $18 \%$ per year which indicates that system needs about 6 years to revert to the long run equilibrium. The results from Granger causality test in Table 5 show direct and indirect short run causality among the variables. Poverty directly Granger caused entrepreneurship. Unemployment and GDP indirectly caused entrepreneurship through poverty. Both the direct and indirect causality found reflect the existence of refugee/shop keeper's effect. This finding can contribute to the argument on whether entrepreneurship is relevant and necessary under the present economic condition in which unemployment and poverty is high and GDP is steadily increasing in the country.

The level of unemployment in a country causes people to live without income and accounts for a situation when they cannot afford basic needs and wants. Hence they become poor and necessitated to pursue entrepreneurial activity. High level of unemployment beyond certain critical level does not necessarily induce people to become entrepreneurs in a country (Hamilton, 1989). The indirect causality from GDP to entrepreneurship through poverty indicates that low GDP due low economic activity and consumer demand causes poverty which consequently pushes poor people to engage in entrepreneurial activity. This situation creates necessity entrepreneurs who will make little impact to the economy. They may exit from entrepreneurship as soon as the situation improves because they were not motivated by opportunity in market.

The diagnostic test results are presented in table 6 which indicate that the model is robust and satisfactorily proven. The estimated residuals have followed normal distribution pattern, the residual are serially 
uncorrelated, there is no problem of misspecification and there is evidence of homoscedesticity of variance. Moreover, the recursive parameter estimate of CUSUM and CUSUM of square tests are presented in Figures 1 and 2 respectively (see Appendix 1). The tests indicate that the model is relatively stable as the cumulative values fall within the two standard deviations boundaries at $5 \%$ level of significance.

Table 6. Diagnostic test

\begin{tabular}{ccccc}
\hline AR & ARCH & RESET & JB & White \\
\hline 1.050 & 0.349 & 0.998 & 0.858 & 0.905 \\
$(0.365)$ & $(0.907)$ & $(0.327)$ & $(0.651)$ & $(0.538)$ \\
\hline
\end{tabular}

Note: AR and ARCH are the Lagrange multiplier tests for serial autocorrelation and ARCH effect respectively. RESET refers to Ramsey Reset specification test. JB is the Jarque Bera statistics for residual normality test and White refers to White general heteroscedesticity test. Figures in parenthesis are $p$ - value.

\section{Variance decompositions (VDCs)}

The variance decompositions gauged the strength of the causal relationship among all the variables in the system. This dynamic analysis beyond the sample strengthened the empirical evidence from the earlier Granger causality analyses. Table 7 shows the decompositions of the forecast error variances of each variable in the system up to 50 years. The analysis can be summarized in the following manner; first, the result indicates that LUEM is the most exogenous variable in the system with only $9 \%$ of its forecast error variance being explained by the other variables. Secondly, LPOV is the most interactive variable in the system, about $93 \%$ of its forecast error variance is explained by LENT (72\%), LUEM (12\%) and LGDP (8\%). Therefore poverty is most endogenous variable and this strengthens the evidence of causality running from unemployment and economic growth to poverty. Thirdly, the changes in LENT happen largely as a result of movement in LUEM. The effect of LUEM on LENT is increasing as the time horizon (years) is also increasing.

\section{Generalized impulse response functions (GIRFs)}

The system as earlier mentioned has four dimensional variables. Therefore 12 possible scenarios of GIFRs are presented for all the variables after disregarding each variable's own shock. The Figure 3 (Appendix 2) shows the visual illustrations of the GIRFs up to 50 years. In most of the result the variables exhibit rapid responses to the shocks, they move fast until after 5 years when they become stable. Moreover, LENT respond negatively due to shock in LPOV that indicate the existence of negative relationship between 
them. LPOV respond positively due to shock in LUEM and respond negatively due to shock in LGDP

Table 7. Generalized variance decompositions (VDCs)

\begin{tabular}{|c|c|c|c|c|c|c|c|}
\hline \multicolumn{8}{|c|}{ Percentage of forecast variance explained due to innovation: } \\
\hline \multicolumn{2}{|c|}{ Horizon } & & $\Delta$ LENT & $\triangle \mathrm{LPOV}$ & $\triangle$ LUEM & $\Delta$ LGDP & $\Delta \mathrm{CV}$ \\
\hline \multirow[t]{10}{*}{ Years } & 1 & $\begin{array}{l}\text { Relative variance in } \\
\Delta \text { LENT }\end{array}$ & 100.000 & 0.000 & 0.000 & 0.000 & 0.000 \\
\hline & 2 & & 84.301 & 0.143 & 15.098 & 0.457 & 15.699 \\
\hline & 10 & & 68.011 & 0.965 & 30.779 & 0.245 & 31.989 \\
\hline & 30 & & 65.841 & 0.971 & 33.016 & 0.172 & 34.159 \\
\hline & 50 & & 65.392 & 0.972 & 33.478 & 0.157 & 34.608 \\
\hline & 1 & $\begin{array}{l}\text { Relative variance in } \\
\triangle \mathrm{LPOV}\end{array}$ & 0.358 & 99.642 & 0.000 & 0.000 & 0.358 \\
\hline & 2 & & 11.937 & 83.354 & 1.303 & 3.406 & 16.646 \\
\hline & 10 & & 63.211 & 18.002 & 12.267 & 6.521 & 81.998 \\
\hline & 30 & & 71.139 & 8.567 & 12.410 & 7.884 & 91.433 \\
\hline & 50 & & 72.600 & 6.828 & 12.436 & 8.136 & 93.172 \\
\hline & 1 & $\begin{array}{l}\text { Relative variance in } \\
\triangle \text { LUEM }\end{array}$ & 2.247 & 2.400 & 95.353 & 0.000 & 4.647 \\
\hline & 2 & & 3.012 & 1.407 & 95.481 & 0.100 & 4.519 \\
\hline & 10 & & 1.178 & 5.803 & 92.231 & 0.788 & 7.769 \\
\hline & 30 & & 0.795 & 7.248 & 90.808 & 1.149 & 9.192 \\
\hline & 50 & & 0.713 & 7.561 & 90.499 & 1.228 & 9.501 \\
\hline & 1 & $\begin{array}{l}\text { Relative variance in } \\
\Delta \mathrm{LGDP}\end{array}$ & 6.586 & 0.062 & 3.996 & 89.356 & 10.644 \\
\hline & 2 & & 14.499 & 0.318 & 3.155 & 82.028 & 17.972 \\
\hline & 10 & & 28.836 & 4.423 & 0.348 & 66.394 & 33.606 \\
\hline & 30 & & 30.196 & 4.896 & 0.137 & 64.770 & 35.230 \\
\hline & 50 & & 30.426 & 4.976 & 0.102 & 64.496 & 35.504 \\
\hline
\end{tabular}

Note: Figures in first column is horizons in years. The column in bold represents the impact of each variable's own shock. The last column provides the percentages of forecast error variances of each variable explained by the other variables. All figures in table are rounded to 3 decimal places.

\section{Conclusion}

The interest in this study came as a result of the observed dwindling socioeconomic conditions in Nigeria and a question whether entrepreneurship could be relevant and necessary in addressing myriad socio-economic problems. Therefore the paper examines the influence of poverty, unemployment and GDP on entrepreneurship. The existence of a long run relationship among 
entrepreneurship, poverty, unemployment and GDP has been found and the Granger causality result shows that poverty directly causes entrepreneurship, while unemployment and GDP indirectly cause entrepreneurship entry. The causality from unemployment to entrepreneurship entry strengthens the evidence of refugee/shop keepers' effect which means unemployment causes people to engage in entrepreneurship in Nigeria. It is discovered that poverty and GDP influence entrepreneurship negatively which indicates that the existing entrepreneurs are likely to be an opportunity entrepreneurs and supports Schumpeterian/prosperity effect hypothesis. The negative influence of poverty on entrepreneurship is not anticipated as poverty is expected to increase entrepreneurship in the country, but it is found that poverty cannot stimulate entrepreneurship.

The positive influence of unemployment on entrepreneurship is an indication of the presence of necessity entrepreneurs and it supports push/ refugee effect hypothesis. Therefore, the paper reveals the presence of both necessity and opportunity entrepreneurship in the country. Necessity entrepreneurship could create job and income in the short run, thereby reducing the social problem. Unemployed and poor people often have feelings of dissatisfaction about their entrepreneurial involvement which may result in their exit from entrepreneurship as soon as they get an alternative paid job. Opportunity entrepreneurs are innovative individuals who create disequilibrium in the economy. The prevalence of this type of entrepreneurs in a country may result in more innovations, high competition and economic growth in both short and long run. Schumpeterian entrepreneurs are opportunity driven, productive and high impact individuals who are carrying out new combinations (innovation) and contribute towards economic development. The paper contributes significantly in providing useful information to various stakeholders for effective policy formulation towards entrepreneurship development.

The paper also contributes to the theory and literature of entrepreneurship in the Nigeria context. The Schumpeter's theory of economic development is based on the assumption that entrepreneurs are innovative and can stimulate GDP. Entrepreneurship may not necessarily drive and stimulate the desired GDP if it is driven by necessity. It is also expected theoretically that increase in poverty will automatically increase the rate of entrepreneurship entry. The unexpected negative relationship between entrepreneurship and poverty shows that poverty may not necessarily cause people to engage in entrepreneurship because of probable lack of start-up capital. 


\section{Practical implications and direction for further research}

There is a need for the government to revisit the existing policy on micro, small and medium enterprises (MSMEs) to adequately address the problem of the poor and unemployed in order to avail them with the opportunity to engage in entrepreneurship. There will be an increase in the rate of crime and other social vices where majority of poor and unemployed people are left without employment or incentives to partake in entrepreneurial activities. Lack of necessary infrastructure could affect the performance of business, income and subsequently lead to a closure of the enterprises. Therefore the government should place high priority in boosting electricity generation and supply so as to reduce the cost of operation and make the business environment more competitive, conducive and friendly for entrepreneurial activity.

The paper focuses on some selected macroeconomic variables in examining their influence on entrepreneurship in Nigeria. Measuring entrepreneurship at the aggregate level is a difficult and complex task. Using new business creation as a proxy may not always be appropriate because sometimes it is not easy to distinguish between legal and illegal business activity. The total number of micro and small businesses registered (as business name) annually was used without filtering or removing the number of those businesses that ceased to exist. There is no official record of those registered businesses that stopped operating as micro or small businesses over the years. Many businesses were not included in the study because they did not register with the government agency as such their number will not be reflected in the list of new business created in the country.

This study is limited in scope but provides sufficient evidence on the factors that influence entrepreneurship in Nigeria. In future, similar study should mitigate the effect of frequent entry and exit from entrepreneurship in the data and effort should be made to filter and consider those with genuine business interest in order to correctly predict the effect of entrepreneurship on the economy. The rate of new business creation varies according to sectors and industries from year to year, therefore there is need to look at individual sector on how entrepreneurship is affected rather than taking analysis on the whole sectors of the economy.

\section{References}

Acs, Z. J. (2007). How entrepreneurship is good for economic growth? a paper presented at the $25^{\text {th }}$ economic conference of progress foundation cosponsored by American Institute for Economic Research (AIER) in Great Barrington, Massachusetts. 
Acs, Z.J., Desai, S., Hessels, J. (2008). Entrepreneurship, economic development and institutions. Small Business Economics, 31, 219-234.

Akoum, I.F. (2008). Globalization, growth, and poverty: The missing link. International Journal of Social Economics, 35(4), 226-238.

Audrestch, D.B., Thurik, A.R. (2000). Capitalism and democracy in the $21^{\text {st }}$ century: From the managed to the entrepreneurial economy. Journal of Evolutionary Economics, 10, 17-34.

Audretsch, D.B., Carree, M.A., Thurik, A.R. (2001). Does entrepreneurship reduce unemployment? Tinbergen Institute Discussion Paper TI 2001074/3, Rotterdam.

Audretsch, D.B., Fritsch, M. (1994). The geography of firm births in Germany, Regional Studies, 28(4), 359-365.

Audretsch, D.B., Keilbach, M. (2004). Entrepreneurship capital: Determinants and impact on regional economic performance, MPI Discussion Paper No. 3704. Jena: Max Planck Institute of Economics.

Audretsch, D.B., Jin, J. (1994). a reconciliation of the unemployment: New firms start up paradox. Small Business Economics, 6,381-385.

Bahmain-Oskooee, M. (1995). The long run determinants of the US trade balance revisited. Journal of Post Keynesian Economics, 17(3), 457- 465.

Block, J., Sandner P. (2009). Necessity and opportunity entrepreneurs and their duration in self-employment: Evidence from German micro data. Journal of Industry, Competition and Trade, 9,117-137.

Bosma, N., Acs, Z.J., Autio, E., Coduras, A., Levie, J. (2008). Executive report. Global Entrepreneurship Monitor (GEM).

Carree, M. (2002). Does unemployment affect the number of establishments? a regional analysis for U.S. states, Regional Studies, 36(4), 389-398.

Carree, M.A., van Stel, A.J., Thurik, A.R., Wennekers, A.R.M.(2002). Economic development and business ownership: An analysis using data of 230ECD countries in the period 1976-1996. Small Business Economics, 1,271-290.

Evans, D.S., Leighton, L.S. (1989). Some empirical aspects of entrepreneurship. American Economic Review, 79, 519-535.

Evans, D.S., Leighton, L.S. (1990). Small business formation by unemployed and employed workers. Small Business Economics, 2(4), 319-330.

Faria, J.R., Cuestas, J.C., Mourelle, E. (2010). Entrepreneurship and unemployment: a non-linear bidirectional causality. Economic Modelling, 27(5),1282-1291.

Garofi, G. (1994). New firm formation and regional development: The Italian case. Regional Studies, 28(4), 381-394.

Gujarati, D.N., Porter, D.C. (2009). Basic econometrics. Singapore: McGraw- Hill Companies Inc.

Hamilton, R.T. (1989). Unemployment and business formation rates: Reconciling time Series and Cross Section Evidence. Environment and Planning, 21, 249-255. 
Hartog, C. Parker, S., Stel, A., Thurik, R. (2010). The two way relationship between entrepreneurship and economic performance. EIM research report H200822, July 2010.

Highfield, R., Smiley, R. (1987). New business starts and economic activity: An empirical investigation. International Journal of Industrial Organization, 5, 51-66.

Johansen and Jesulius (1990). Maximum likelihood estimation and inference on cointegration with application to the demand for money. Oxford Bulletin of Economics and Statistics, 52, 169-244.

Jones-Evans, D., Brookbark, D., Aaron, E. (2006). Public support programmes for high growth business in the UK. An exploratory Study. National Entrepreneurship Observatory, GEM Wales paper series No 7.

Keister , L.A. (2005). Entrepreneurship (Ed.). Netherland: Elsevier Ltd,

Knight, F.H. (1971). Risk, uncertainty, and profit. Chicago: The University of Chicago Press, originally published in 1921 by Houghton Mifflin Company.

Koster, S., Kumar Rai, S. (2008). Entrepreneurship and economic development in a developing country: a case study of India. Journal of Entrepreneurship, $17(2), 117-137$.

Lafuente, E.M. and Driga, O. (2007). Report on entrepreneurial activities in Romania. CEBR working paper series 01-2007.

Meager, N. (1992). Does unemployment lead to self-employment? Small Business Economics, 4, 87-103.

Mojica-Howell, M.N., Whittaker W.L., Gebremedhin, T.G., Schaeffer, P.V. (2012). Examining the bidirectional relationship between entrepreneurship and economic growth: Is entrepreneurship endogenous?, Entrepreneurship - born, made and educated, Prof. Thierry Burger-Helmchen (Ed.), ISBN: 978-953-51-0210-6, InTech, Available from: http://www.intechopen. com/books.

Mulira, F., Namatovu, R., Dawa, S. (2011). Panacea or Precipitate. "The Entrepreneurship and Poverty Paradox". Retrieved from www.aibuma. org/proceedings.

Naude, W., Amoros, J.E., Cristi, O. (2012). Surfeiting, the appetite may sicken: entrepreneurship and the happiness of nations. UNU MERIT working paper 2012-013.

NBS (2010). The review of the Nigerian economy. National Bureau of Statistics.

Plehn-Dujowich, J.M. (2012). The dynamic relationship between entrepreneurship, unemployment and growth: Evidence from US Industries, SBA research report No 394.

Reynolds, P., Storey, D.J., Westhead, P. (1994). Cross national comparisons of the variation in new firm formation rate. Regional Studies, 28(4), 443- 456. 
Ritchie, B., Lam, W. (2006). Taking the stock of small business and entrepreneurship research. International Journal Entrepreneurial Behavior and Research, 12(6),312-327.

Ritsila, J., Tervo, H. (2002). Effects of unemployment on new firm formation: Micro level panel data evidence from Finland. Small Business Economics Journal, 19, 31-40.

Rosa, P.J., Kodithuwakku, S., Balunywa, W. (2006). Entrepreneurial motivation in developing countries: What does "Necessity and opportunity really mean". Frontier of Entrepreneurship Research, 26(20), Chapter XX Micro Entrepreneurship.

Salgado-Banda, H. (2005). Entrepreneurship and economic growth: An empirical analysis. Seminar paper at University of London.

Sexton, D.L. and Kasarda, J.D. (1992). The state of the art of entrepreneurship. PWS - Publishing Company, Boston, USA

Stel, A., Carree, M., Thurik, R. (2004). The effect of entrepreneurship on national economic growth: An analysis using the GEM database. SCALES paper N200320.

Stel, A., Thurik, R., Verheul, I., Baljeu, L. (2007). The relationship between entrepreneurship and unemployment in Japan. Tinbergen institute discussion paper, TI 2007-080/3.

Sternberg, R. and Wennekers, S. (2005). Determinants and effects of new business creation using global entrepreneurship monitor data. Small Business Economics, 24,193-203.

Stock, J.H. and Watson M.W. (2001). Vector autoregressions. Journal of Economic perspective, 15(4),101-115.

Storey, D.J. (1991). The birth of new firms - does unemployment matter? a review of evidence. Small Business Economic, 3,167-178.

Storey, D.J. (2003). Entrepreneurship: small and medium sized and public policies. Handbook of entrepreneurship research. Kluwer Academic Publishers, Amsterdam, pp 473-511.

Szirmai, A., 2005. Dynamics of socio-economic development: An introduction. Cambridge University Press: Cambridge, ISBN: 9780521817639, pp 233.

Thurik, R., Carree. M.A., Stel, A., Audretsch, D.B. (2008). Does self-employment reduce unemployment. Journal of Business Venturing, 23(6),673- 686.

UNIDO (2003). Path out of poverty: Developing rural and women entrepreneurship. United nation industrial development organization, 2003 Vienna.

UNCTAD (2004). Entrepreneurship and economic development: The Empretec show Case. United Nation Conference on Trade and Development Publication January 2004.

Verheul, I., Thurik, R. Hessel, J., van der Zwan, P. (2010). Factors influencing the entrepreneurial engagement of opportunity and necessity entrepreneurs. EIM. Retrieved from http://www.entrepreneurship-sme.eu. 
Wagner, J. (2005). "Der noth gelorchand, Nicht dem eignen tried"- Necessity and opportunity entrepreneurs in Germany: Evidence from the regional entrepreneurial Monitor. IZA Discussion Paper No 1608.

Wang, S. (2006). Determinant of new firm formation in Taiwan. Small Business Economic, 27,313-321.

Wennekers, S., Van stel, A, Thurik, R., Reynolds, P. (2005). Nascent entrepreneurship and the level of economic development. Small Business Economics, 24,293-309.

Yamawaki, H. (1990). The effects of business conditions on net entry: Evidence from Japan. In P.A. Geroski and J. Schwalbach (Eds.), Entry and Market Contestability: An International Comparison.Oxford: Basil Blackwell.

\section{Appendix 1}

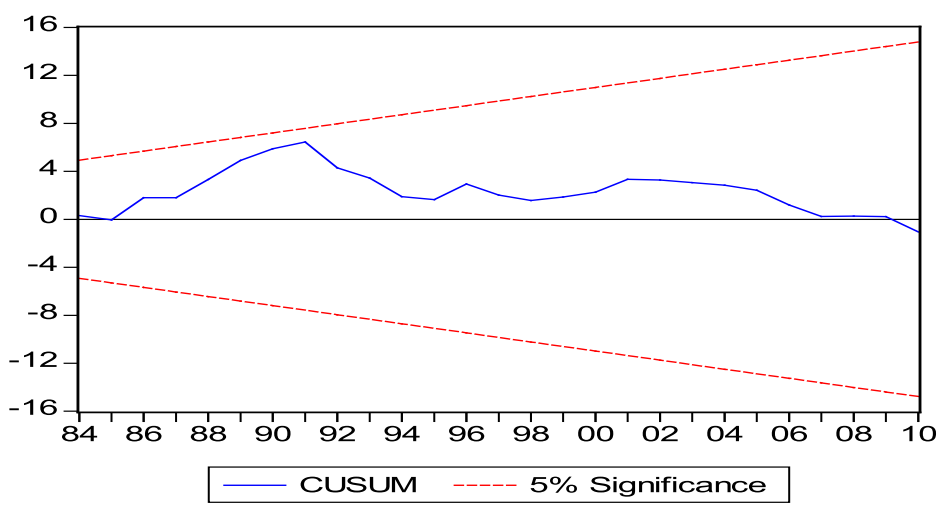

Figure 1. CUSUM Test

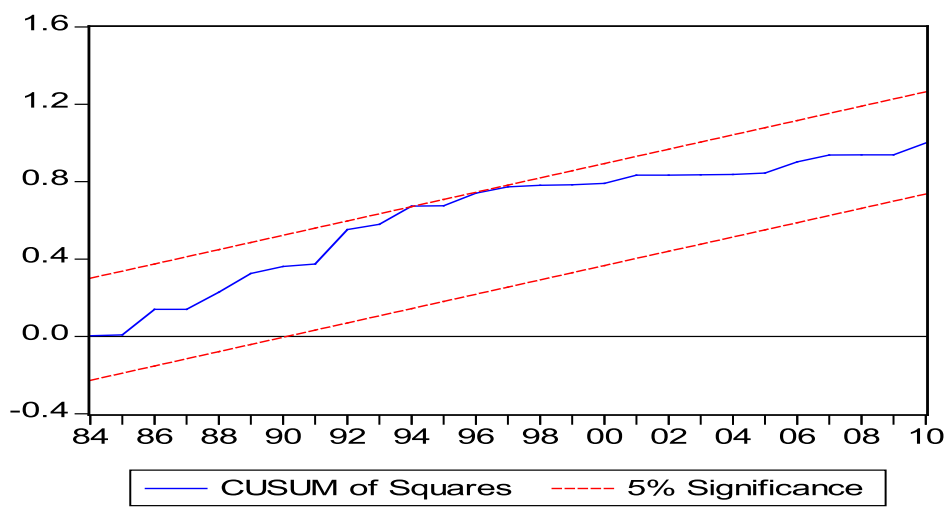

Figure 2. CUSUM OF SQUARE Test 


\section{Appendix 2}

Response to Generalized One S.D. Innovations
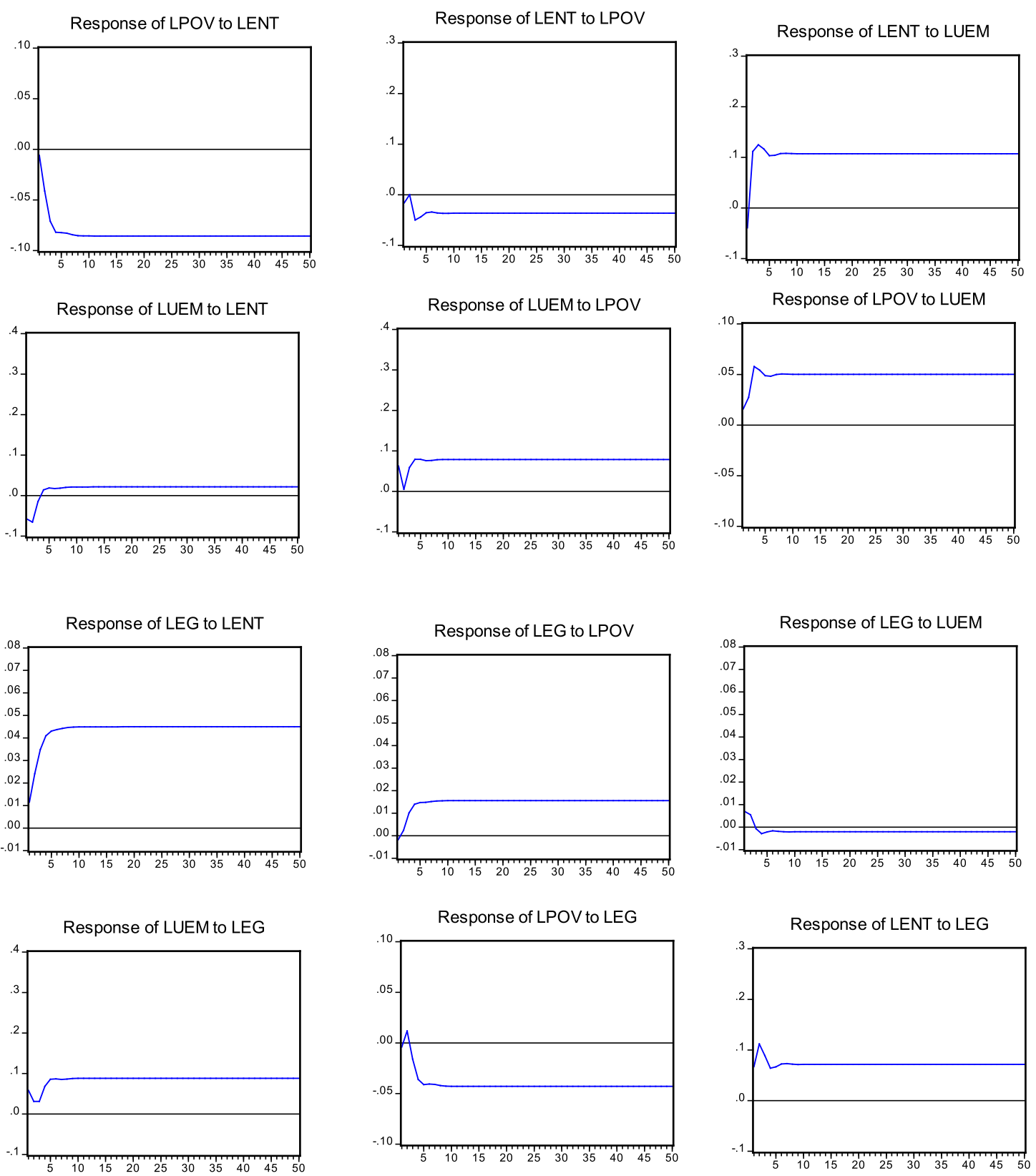

Figure 3 Generalized impulse response functions (IRFs) 


\begin{abstract}
Abstrakt (in Polish)
Celem artykułu jest zbadanie wpływu ubóstwa, bezrobocia i PKB na przedsiębiorczość. Dla potrzeb tej analizy zgromadzono dane za okres trzydziestu jeden lat wykorzystujqc rozmaite oficjalne źródła. Zastosowano model wektorowej autoregresji (VAR), aby systematycznie ujać bogatq dynamikę wielokrotnych serii czasowych. Inne przeprowadzone testy obejmowały jednostkowy test pierwiastka, test ko-integracji Johansena i Juseliusa (1990), Model przyczynowości Grangera i analizę dynamicznego modelu wykraczajqca poza próbkę. Okazało się, że ubóstwo i PKB negatywnie wpływajq na przedsiębiorczość, natomiast bezrobocie ma na niq wpływ pozytywny. Artykuł ujawnia zarówno obecność przedsiębiorców wykorzystujq̨cych możliwości, jak i tych z konieczności w badanym państwie. Istnieje potrzeba, aby rzqd dokonat rewizji swojej polityki dotyczqcej mikro-, małych i średnich przedsiębiorstw aby odpowiednio zareagować na problem ludzi biednych i bezrobotnych, dajq̨c im możliwość zaangażowania się w przedsiębiorczość. Przyszłe badania powinny zajqć się zminimalizowaniem efektu częstego rozpoczynania i kończenia działalności przedsiębiorczej, tak by prawidłowo przewidzieć wpływ przedsiębiorczości na gospodarkę.
\end{abstract}

Słowa kluczowe: rozwój przedsiębiorczości, ubóstwo, bezrobocie, PKB. 